\title{
A Proteomics Analysis to Evaluate Cytotoxicity in NRK-52E Cells Caused by Unmodified Nano- $\mathrm{Fe}_{3} \mathrm{O}_{4}$
}

\author{
Yi-Reng Lin, ${ }^{1}$ Chao-Jen Kuo, ${ }^{2}$ Hugo You-Hsien Lin, ${ }^{2,3,4}$ \\ Chin-Jen Wu, ${ }^{5}$ and Shih-Shin Liang ${ }^{6,7}$ \\ ${ }^{1}$ Department of Biotechnology, Fooyin University, 151 Jinxue Road, Kaohsiung 83102, Taiwan \\ ${ }^{2}$ Graduate Institute of Medicine, Kaohsiung Medical University, 100 Shih-Chuan 1st Road, Kaohsiung 80708, Taiwan \\ ${ }^{3}$ Division of Nephrology, Department of Internal Medicine, Kaohsiung Medical University Hospital, Kaohsiung Medical University, \\ 100 Shih-Chuan 1st Road, Kaohsiung 80708, Taiwan \\ ${ }^{4}$ Department of Internal Medicine, Kaohsiung Municipal Ta-Tung Hospital, Kaohsiung Medical University, \\ Kaohsiung, Taiwan \\ ${ }^{5}$ Kaiser Pharmaceutical Co., Ltd., 9 Huan-Gong Road, Tainan 71041, Taiwan \\ ${ }^{6}$ Department of Biotechnology, College of Life Science, Kaohsiung Medical University, 100 Shih-Chuan 1st Road, \\ Kaohsiung 80708, Taiwan \\ ${ }^{7}$ Center for Resources, Research and Development, Kaohsiung Medical University, 100 Shih-Chuan 1st Road, \\ Kaohsiung 80708, Taiwan
}

Correspondence should be addressed to Shih-Shin Liang; liang0615@kmu.edu.tw

Received 21 April 2014; Accepted 5 June 2014; Published 17 August 2014

Academic Editor: Hsueh-Wei Chang

Copyright (C) 2014 Yi-Reng Lin et al. This is an open access article distributed under the Creative Commons Attribution License, which permits unrestricted use, distribution, and reproduction in any medium, provided the original work is properly cited.

\begin{abstract}
We synthesized unmodified $\mathrm{Fe}_{3} \mathrm{O}_{4}$ nanoparticles (NPs) with particles size from $10 \mathrm{~nm}$ to $100 \mathrm{~nm}$. We cultured NRK-52E cell lines (rat, kidney) and treated with $\mathrm{Fe}_{3} \mathrm{O}_{4}$ NPs to investigate and evaluate the cytotoxicity of NPs for NRK-52E cells. Through global proteomics analysis using dimethyl labeling techniques and liquid phase chromatography coupled with a tandem mass spectrometer (LC-MS/MS), we characterized 435 proteins including the programmed cell death related proteins, ras-related proteins, glutathione related proteins, and the chaperone proteins such as heat shock proteins, serpin H1, protein disulfide-isomerase A4, endoplasmin, and endoplasmic reticulum resident proteins. From the statistical data of identified proteins, we believed that NPs treatment causes cell death and promotes expression of ras-related proteins. In order to avoid apoptosis, NRK-52E cell lines induce a series of protective effects such as glutathione related proteins to reduce reactive oxygen species (ROS), and chaperone proteins to recycle damaged proteins. We suggested that, in the indigenous cellular environment, $\mathrm{Fe}_{3} \mathrm{O}_{4} \mathrm{NPs}$ treatment induced an antagonistic effect for cell lines to go to which avoids apoptosis.
\end{abstract}

\section{Introduction}

In general, nanoparticles (NPs) are a group of particles with diameter size between one nanometer to one hundred nanometers. NPs have properties such as a high specific surface area and have a high potential to be a good catalytic agent, and therefore NPs have been widely used in fields such as antibacterial [1], antimicrobial [2,3], drug delivery [4], and global use in research $[5,6]$. However, having high catalytic potential, NPs were modified with polysaccharide or chitosan to avoid cytotoxicity $[2,3]$. Based on the response of toxicity, NPs such as those that use silver and titanium dioxide were evaluated for cytotoxicity, DNA damage, and reactive oxygen species (ROS) [7-9]. Especially in AgNPs, numerous studies showed that in cellular responses, $100 \mathrm{~nm}$ AgNPs induced serine/threonine protein kinase (PAK), phosphatase $2 \mathrm{~A}$, and mitogen-activated protein kinase (MAPK) pathways, and $20 \mathrm{~nm}$ AgNPs induced ROS, SUMOylation, and protein carbonylation [10]. Moreover, published papers increasingly show that proteomics analysis and LC-MS/MS were utilized 
to demonstrate the effects of NPs, such as quantitative proteomics to evaluate AgNPs exert cellular responses [10], AgNPs treatment directly involved in ROS, metal detoxification according to genomics and proteomics results [11], and the toxic effects and behavior in Caenorhabditis elegans [12].

Previous studies reported that in vitro experiments and AgNPs exposure directly induced ROS, cell death, apoptosis, and inflammation $[13,14]$. In animal model studies, female rats had AgNPs accumulation in kidney regions, especially in the glomerulus [15]. A variety of reports showed evidence that AgNPs treatment has cytotoxicity in proteomics and genomics; however no evaluated studies of other NPs are described with $\mathrm{Fe}_{3} \mathrm{O}_{4}$ or gold nanoparticles.

MS-based quantitative proteomics has been developed at a marvelous rate in the past two decades for biomarker discovery and drug screening. In addition, proteomics provides numerous proteins expression profiles using quantitative techniques to estimate and established the relationships using bioinformatics software. Current quantitative comparisons between specimens both with drug treatment and without treatment or normal and abnormal tissues are beneficial to identify the proteins with upregulation or downregulation and to set up biologic mechanisms and pathways $[16,17]$. However in complicated tissue specimens, abundant proteins interfere with the detection of rare proteins. Multiple dimensional separation systems were used to fractionate peptides into different fractions through liquid phase chromatography (LC) to decrease the samples' complication and to increase the amount of protein identification $[16,18]$.

In this work, we synthesized bare $\mathrm{Fe}_{3} \mathrm{O}_{4}$ NPs and characterized the size of NPs by transmission electron microscope (TEM). After treatment with unmodified $\mathrm{Fe}_{3} \mathrm{O}_{4}$ NPs, we next utilized dimethyl labeling quantitative reagents to label the tryptic peptides of NRK-52E cell lines with treated and untreated $\mathrm{Fe}_{3} \mathrm{O}_{4}$ NPs [19]. In global proteomics research coupled with LC-MS/MS, we demonstrated 435 identified proteins in NRK-52E cell lines by Mascot and simultaneously quantitated 311 proteins through the use of Mascot Distiller bioinformatics software. We classified proteins into chaperone proteins, cell death related and apoptotic proteins, ras-related proteins, and glutathione related proteins. Using STRING for protein-protein interaction [20], we demonstrated the relationships between $\mathrm{Fe}_{3} \mathrm{O}_{4}$ NPs and multifarious proteins.

\section{Materials and Methods}

2.1. Chemical Reagents. Sodium acetate, ferric chloride $\left(\mathrm{FeCl}_{3}\right)$, ferrous chloride $\left(\mathrm{FeCl}_{2}\right)$, sodium cyanoborohydride $\left(\mathrm{NaBCNH}_{3}\right)$, and trifluoroacetic acid (TFA) were obtained from Sigma-Aldrich (St. Louis, MO, USA). Acetonitrile (MeCN) was bought from Merck (Seelze, Germany). Ammonium hydrogen carbonate $\left(\mathrm{NH}_{4} \mathrm{HCO}_{3}\right)$, hydrochloric acid, sodium hydroxide, sodium dodecyl sulphate (SDS), and ethanol were purchased from J. T. Baker (Phillipsburg, NJ, USA). Formaldehyde- $\mathrm{D}_{2}$ solution $\left(20 \%\right.$ solution in $\left.\mathrm{D}_{2} \mathrm{O}\right)$ was purchased from Isotec Corp. (Miamisburg, OH, USA), while formaldehyde- $\mathrm{H}_{2}$ solution $\left(36.5 \%-38 \%\right.$ in $\left.\mathrm{H}_{2} \mathrm{O}\right)$, potassium chloride $(\mathrm{KCl})$, sodium chloride $(\mathrm{NaCl})$, sodium dihydrogen phosphate $\left(\mathrm{NaH}_{2} \mathrm{PO}_{4}\right)$, potassium dihydrogen phosphate $\left(\mathrm{KH}_{2} \mathrm{PO}_{4}\right)$, dimethyl sulfoxide (DMSO), formic acid (FA, 98\%-100\%), and iodoacetamide (IAM) were purchased from Sigma (St. Louis, MO, USA). Trypsin was purchased from Promega (Madison, WI, USA). The protein concentration of cell lysate was determined by Bradford assay based on the measurement BSA calibration curve (Thermo, Rockford, IL, USA). Deionized $\mathrm{H}_{2} \mathrm{O}$ with a resistance of $18.2 \mathrm{M} \Omega$ was obtained using a Millipore water system.

2.2. Fabrication of $\mathrm{Fe}_{3} \mathrm{O}_{4}$ Nanoparticles (NPs) by Hydrothermal Precipitation. The nanoscale magnetic iron oxide particles were prepared by hydrothermal homogeneous coprecipitation [21-23]. Ferric chloride $\left(\mathrm{FeCl}_{3}, 5.2 \mathrm{~g}\right)$ and ferrous chloride $\left(\mathrm{FeCl}_{2}, 2.0 \mathrm{~g}\right)$ were dissolved with sonication in $50 \mathrm{~mL}$ clean glassware containing aqueous hydrochloric acid $(2 \mathrm{M}, 25 \mathrm{~mL})$ at $50^{\circ} \mathrm{C}$. Subsequently, the mixture was degassed continuously using a nitrogen gas cylinder. Sodium hydroxide $(\mathrm{NaOH} 150 \mathrm{~mL}, 2 \mathrm{M})$ was slowly injected drop by drop into the glassware. The color of the solution transformed from yellow to orange, and finally the color shifted to black through the $\mathrm{NaOH}$ dripping down. After incubation at $50^{\circ} \mathrm{C}$ for one hour, the supernatant was removed through a strong magnet absorbing NPs. The generated NPs were then washed with deionized water and removed by a centrifugal tube with $1,800 \mathrm{rpm}$ for two minutes. Then finally the NPs were rinsed with $0.5 \mathrm{M} \mathrm{HCl}$, deionized water and ethanol sequentially.

2.3. Characterization of $\mathrm{Fe}_{3} \mathrm{O}_{4}$ by Transmission Electron Microscope (TEM). The size of the synthetic $\mathrm{Fe}_{3} \mathrm{O}_{4} \mathrm{NPs}$ was characterized by a JEOL JEM 1200-EX transmission electron microscope (TEM) with the accelerating voltage $80 \mathrm{keV}$. One $\mu \mathrm{L}$ of the nanoparticles solution was dropped on a cupric grid with stabilized carbon, and subsequently the surplus solution evaporated in the atmosphere.

2.4. NRK-52E Cell Culture, the Conditions of $\mathrm{Fe}_{3} \mathrm{O}_{4}$ NPs Treatment, and Protein Concentration. The cells, NRK-52E (CRL1571; American Type Culture Collection, Manassas, VA), were cultured in Dulbecco's modified Eagle's medium (DMEM, Sigma-Aldrich) and supplemented with 5\% fetal bovine serum (FBS) and 1\% penicillin (Gibco, Grand Island, NY, USA). Cells were cultured in a $100 \mathrm{~mm}$ dish with a $5 \% \mathrm{CO}_{2}$ incubator at $37^{\circ} \mathrm{C}$. Until cells reached $80 \%$ confluence, they were cultured with the absence of serum medium for 24 hours. After starvation cells were treated with 1 ng $\mathrm{Fe}_{3} \mathrm{O}_{4}$ NPs in each dish for 24 hours, and comparison groups were treated with dimethyl sulfoxide (DMSO). After being washed three times with phosphate-buffered saline (PBS), the cells were lysed with modified RIPA buffer containing $1 \%$ NP-40, $0.1 \%$ SDS, $150 \mathrm{mM} \mathrm{NaCl}, 50 \mathrm{mM}$ Tris- $\mathrm{HCl}$, and 1 tablet $/ 10 \mathrm{~mL}$ of Roche minicomplete protease inhibitor cocktail at $\mathrm{pH} 7.5$. Finally, the protein concentration of NRK-52E cell lysate was determined using the Bradford assay.

2.5. Tryptic Digestion, Dimethyl Labeling, Desalting, and Fractionation. Samples of lysated protein solution $60 \mu \mathrm{L}$ 
containing $100 \mu \mathrm{g}$ of total proteins treated with $\mathrm{Fe}_{3} \mathrm{O}_{4} \mathrm{NPs}$ and DMSO were reduced by reaction with $0.7 \mu \mathrm{L}$ of $1 \mathrm{M}$ DTT and $9.3 \mu \mathrm{L}$ of $7.5 \%$ SDS at $95^{\circ} \mathrm{C}$ for 5 minutes. The sample bottles were put on ice and then for alkylation were treated with $8 \mu \mathrm{L}$ of $50 \mathrm{mM}$ IAM at room temperature for 30 minutes in the dark with agitation. Furthermore, sample proteins were precipitated by $52 \mu \mathrm{L}$ of $50 \%$ trichloroacetic acid (TCA) with incubation on ice for 15 minutes. By centrifugation to remove the supernatant, the protein pellets were washed in different solutions according to priority with $150 \mu \mathrm{L}$ of $10 \%$ TCA, $250 \mu \mathrm{L}$ of deionized $\mathrm{H}_{2} \mathrm{O}, 250 \mu \mathrm{L}$ of acetone, and two times with $250 \mu \mathrm{L}$ of deionized $\mathrm{H}_{2} \mathrm{O}$. After removing the supernatant, the protein pellets were digested in $2 \mu \mathrm{g}$ of trypsin in $200 \mu \mathrm{L} 50 \mathrm{mM} \mathrm{NH}_{4} \mathrm{HCO}_{3}$ $(\mathrm{pH}$ 8.5). An additional $2 \mu \mathrm{g}$ of trypsin was added after 4 hours of tryptic digestion, and then the samples were digested for 14 hours at $37^{\circ} \mathrm{C}$. Eventually the tryptic digestion samples were dried by vacuum centrifugation to remove the digested buffer. For labeling procedures, the lyophilized samples were redissolved in $180 \mu \mathrm{L}$ of $100 \mathrm{mM}$ sodium acetate buffer at $\mathrm{pH}$ 5.5. Simultaneously the treated NPs samples were labeled using $10 \mu \mathrm{L}$ of $4 \%$ formaldehyde- $\mathrm{D}_{2}$ and then those samples treated DMSO were labeled using $10 \mu \mathrm{L}$ of $4 \%$ formaldehyde- $\mathrm{H}_{2}$. Both of the samples were vortexed for 5 minutes, followed by treatment with $10 \mu \mathrm{L}$ of $600 \mathrm{mM}$ sodium cyanoborohydride for 1 hour. Finally, the labeled solutions were combined after adjusting to $\mathrm{pH} 2-3$ using $10 \%$ TFA/ $\mathrm{H}_{2} \mathrm{O}$ for desalting by a homemade $\mathrm{C} 18$ cartridge desalting kit. After vacuum centrifugation drying, the triplicate combined samples were fractionated with a hydrophilic interaction chromatography (HILIC) separated system. HILIC system was performed using an L-7100 pump system (Hitachi, Tokyo, Japan) connecting a TSK gel Amide- 80 HILIC column $(2.0 \mathrm{~mm} \times 150 \mathrm{~mm}, 3 \mu \mathrm{m}$ particle size; Tosoh Biosciences, Tokyo, Japan) with a flow rate of $200 \mu \mathrm{L} / \mathrm{min}$. The mobile phase system was used for gradient elution: solvent (A) was $0.1 \%$ TFA in water; solvent (B) was $0.1 \%$ TFA in $100 \% \mathrm{MeCN}$. The eluted fraction from the homemade $\mathrm{C} 18$ cartridge was dissolved in $25 \mu \mathrm{L}$ of solution containing $85 \% \mathrm{MeCN}$ and $0.1 \%$ TFA and then injected into the $20 \mu \mathrm{L}$ sample loop. Furthermore, the gradient was performed as follows: $95 \%$ (B) for 2 minutes; $95 \% \sim 60 \%$ (B) for 32 minutes; $60 \%$ 5\% (B) for 10 minutes; 5\% (B) for 5 minutes; 5\% 95\% (B) for 1 minute; and $95 \%$ (B) for 10 minutes. Each fraction contained $1.2 \mathrm{~mL}$ buffer in the total of 10 collected fractions, and finally every fraction was dried in a vacuum centrifuged system.

2.6. Protein Identification by LC-MS/MS Analysis. The vacuum dried lyophilized samples were redissolved in $10 \mu \mathrm{L}$ of $0.1 \%$ FA in $\mathrm{H}_{2} \mathrm{O}$ and analyzed using a Thermo LTQ Orbitrap XL (Thermo Fisher Scientific, San Jose, CA). A total of $10 \mu \mathrm{L}$ of sample was injected onto a C18 capillary pretrapped column $(0.3 \mathrm{~mm} \times 5 \mathrm{~mm}, 5 \mu \mathrm{m}$ particle size, Agilent Zorbax $\mathrm{XDB})$; HPLC loading pump and separation was performed by a $\mathrm{C} 18$ column (i.d. $75 \mu \mathrm{m} \times 150 \mathrm{~mm}, 3 \mu \mathrm{m}$ particle size, Micro Tech, Fontana, CA). A LC-MS/MS separation was performed using an Agilent 1200 series Nanoflow pump (Agilent Technologies, Santa Clara, CA). The flow rate of loading pump was set at $5 \mu \mathrm{L} / \mathrm{min}$, and the gradient pump was set at $300 \mathrm{~nL} / \mathrm{min}$. The mobile phases consisted of (A) $0.1 \%$ FA in water and (B) $0.1 \% \mathrm{FA}$ in $100 \% \mathrm{MeCN}$. The linear gradient was as follows: $2 \%$ (B) in 2 minutes, $2 \% \sim 40 \%$ (B) in 40 minutes, $40 \%$ 95\% (B) in 8 minutes, 95\% (B) in 2 minutes, 95\% $2 \%$ (B) in 1 minute, and 2\% (B) in 7 minutes. The digested peptides were detected by a voltage of $1.8 \mathrm{kV}$ in the positive detection ion mode. The separated system with full scanning mode conditions was set at $m / z 400-1600 \mathrm{Da}$ with resolution $=30,000$. The data-dependent mode was set according to a priority to select peptides which were detected with 5 high-intensity signals in the MS mode and transferred into collision chamber for fragmentation with a collision energy of $35 \mathrm{eV}$. The fragmented ions were analyzed and detected at second MS analyzer with a mass range of $m / z 100-2000 \mathrm{Da}$. To exclude ions with similar $m / z$ and avoid interferences, the data-dependent mode was also set a repeat duration of 30 seconds.

2.7. Mascot Database Search and Mascot Distiller Quantitation. The software Xcalibur (version 2.0.7, Thermo Scientific Inc., San Jose, CA) was utilized to control Orbitrap XL and to acquire the MS and fragmentation data. The raw data including MS and MS/MS spectra were converted to a suitable file type by the Mascot Distiller software (version 2.5.1.0 (64 bits), Matrix Science Ltd., London, UK) to perform protein identification and quantitation. The parameters of the Mascot Distiller were set as follows: "Orbitrap_res_MS2" (default parameter setting) for peak list transformation; "Rattus" for the taxonomy in the Swiss-Prot databank of the Mascot search engine; zero allowable missed cleavages for tryptic digestion; dimethylation (MD) for quantitation; fixed modification was selected carbamidomethyl for cysteine modification; peptide tolerance of $10 \mathrm{ppm}$ with precursor ions; and $0.8 \mathrm{Da}$ tolerance for MS/MS. Peptides charge was selected when they had charges of $1^{+}, 2^{+}$, and $3^{+}$, and the instrument was set to "ESI-trap." Finally, the protein quantitative result was listed by the heavy-labeled/light-labeled $(\mathrm{D} / \mathrm{H})$ ratios from the Mascot Distiller.

\section{Results and Discussion}

3.1. $\mathrm{Fe}_{3} \mathrm{O}_{4} \mathrm{NPs}$ Synthesis and Characterization. Bare and unmodified $\mathrm{Fe}_{3} \mathrm{O}_{4}$ NPs were synthesized by hydrothermal precipitation and NPs were fabricated by chemical method to have a uniform particle size. In Figure 1, TEM images showed that we took three photos of $\mathrm{Fe}_{3} \mathrm{O}_{4}$ NPs with $20 \mathrm{~nm}, 50 \mathrm{~nm}$, and $100 \mathrm{~nm}$ scale bars. It is considered that NPs with a higher surface area are easier to aggregate with other NPs; therefore through the aggregation in $\mathrm{Fe}_{3} \mathrm{O}_{4}$ NPs there were $\mathrm{Fe}_{3} \mathrm{O}_{4}$ particles generated above $100 \mathrm{~nm}$ if no additional protective agent was modified onto $\mathrm{Fe}_{3} \mathrm{O}_{4}$ (Figure 1(c)). We considered that $\mathrm{Fe}_{3} \mathrm{O}_{4} \mathrm{NPs}$ with dispersive diameter sizes are suitable for cytotoxicity evaluation due to the fact that NPs found in the environment have random sizes.

3.2. Schematic Representation of Samples Pretreatments, Fractionation, Protein Identification, and Protein Quantitation. 


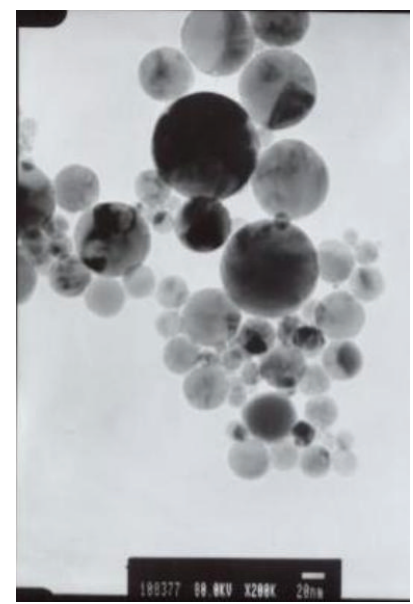

(a)

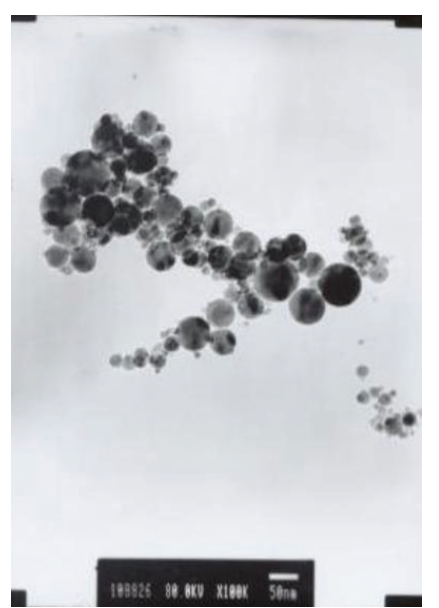

(b)

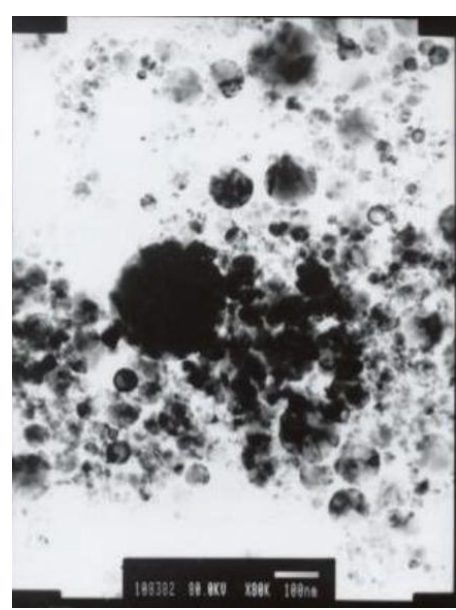

(c)

Figure 1: TEM images of $\mathrm{Fe}_{3} \mathrm{O}_{4}$ NPs with different sizes as follows: (a) $20 \mathrm{~nm}$, (b) $50 \mathrm{~nm}$, and (c) $100 \mathrm{~nm}$ scale bars.

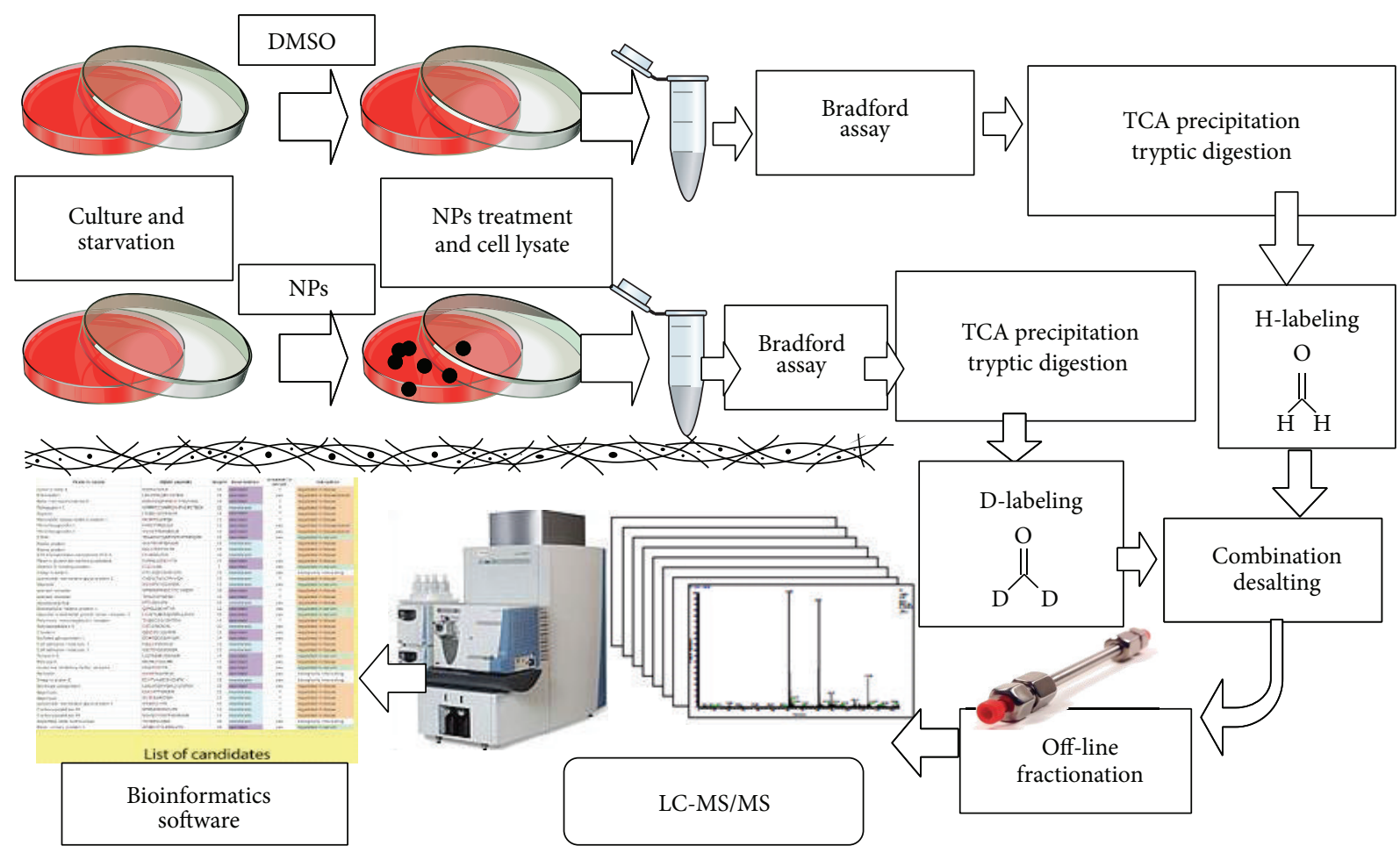

FIGURE 2: Simplified flow chart of sample pretreatment, fractionation, and analysis using LC-MS/MS.

For protein quantitation, the procedures and using reagents including formaldehyde- $\mathrm{H}_{2}$, formaldehyde- $\mathrm{D}_{2}$, and sodium cyanoborohydride $\left(\mathrm{NaBCNH}_{3}\right)$ were obeyed as following the previous literature [19]. By utilization of dimethyl labeling, the differences of protein expressions in treatment with and without NPs was enabled to be determined. In the mass spectrum, the proteins of NRK-52E treated NPs were labeled as formaldehyde- $\mathrm{D}_{2}$ and proteins of untreated NPs were labeled as formaldehyde- $\mathrm{H}_{2}$. In the same sequential peptides, however, different treatments had a mass difference $4 \mathrm{Da}$ or $8 \mathrm{Da}$ depending on the use of the labeling agent. Off-line HILIC fractionation was utilized to decrease the complication of the mixed samples $[16,18]$. Through LC-MS/MS, the proteins identification and quantitative ratios of $\mathrm{D} / \mathrm{H}$ peptides were identified and calculated using the bioinformatic Mascot Distiller software to finally generate a protein list. The 


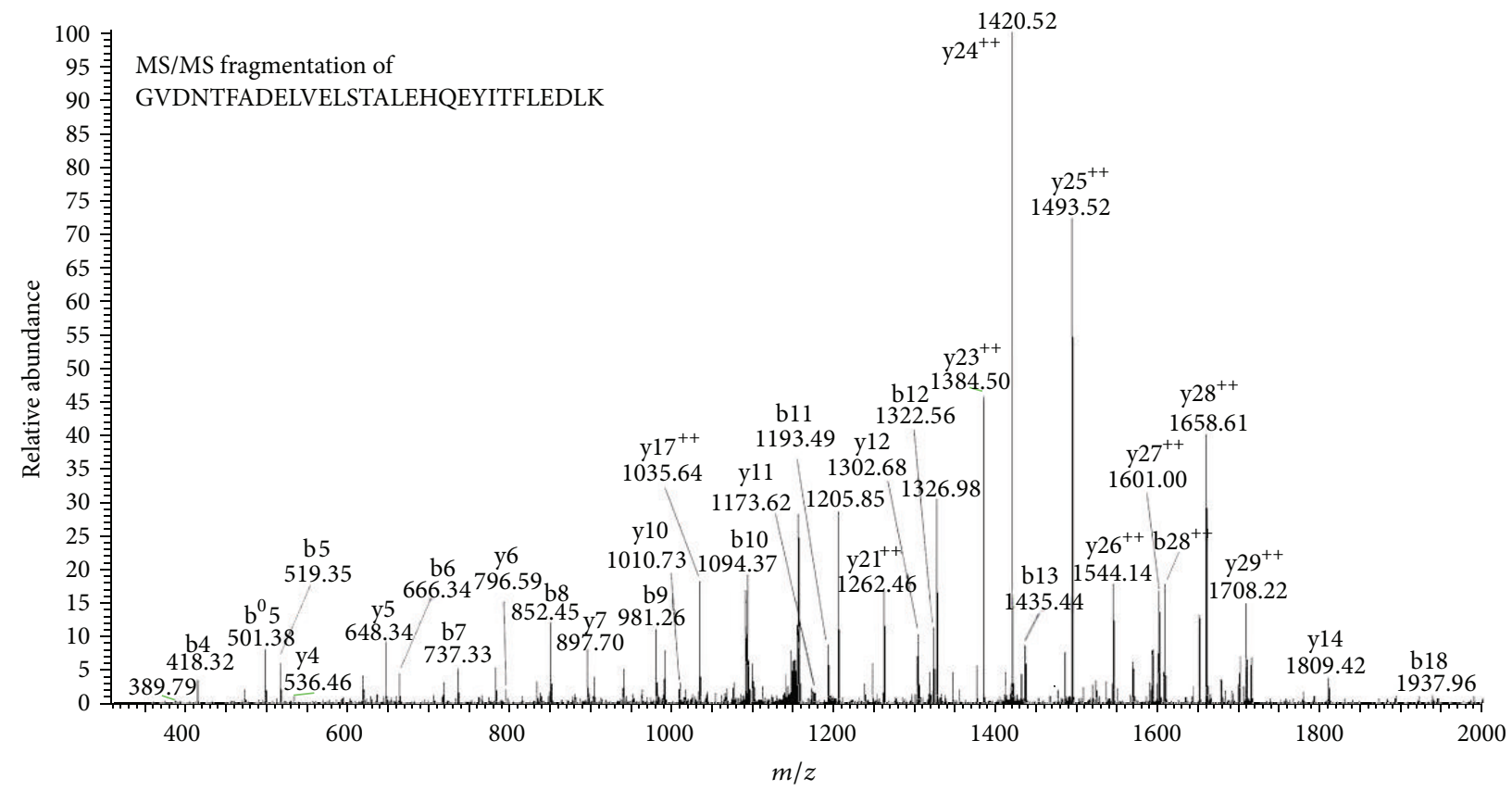

FIGURE 3: MS/MS spectrum of the peptide sequence GVDNTFADELVELSTALEHQEYITFLEDLK $\left(m / z 1168.60,3^{+}\right)$, which is a peptide of complement component $1 \mathrm{Q}$ subcomponent-binding protein (C1qBP).

schematic flow chart of the process is shown in Figure 2 from sample pretreatment and protein identification to protein quantitation.

3.3. Quantitative Results of NRK-52E Proteins Associated with $\mathrm{Fe}_{3} \mathrm{O}_{4} \mathrm{NPs}$. From the statistical results we identified 435 proteins, of which 311 proteins have a $\mathrm{D} / \mathrm{H}$ ratio and 124 proteins which we were unable to specific values. For example, complement component $1 \mathrm{Q}$ subcomponent-binding protein $(\mathrm{ClqBP})$ was identified with an arithmetic average $\mathrm{D} / \mathrm{H}$ ratio of 4.23. Figure 3 showed the peptide belonging to ClqBP having sequences GVDNTFADELVELSTALEHQEYITFLEDLK which was fragmentized by collision induced dissociation (CID), and its MS/MS spectrum was illustrated by $\mathrm{y}$-ions and b-ions. From a quantitative standpoint in support of the Mascot Distiller in bioinformatics software, the result of protein list showed that the $\mathrm{D} / \mathrm{H}$ ratio belonging to GVDNTFADELVELSTALEHQEYITFLEDLK peptide was 4.23. Simultaneously the raw data from LC-MS/MS that we extracted from the labeled peptide of ClqBP by $m / z 1165.92$ $\left(3^{+}, \mathrm{H}\right.$-labeled $)$ and $1168.60\left(3^{+}, \mathrm{D}\right.$-labeled $)$ presented signals of peak area and peak height (Figure 4(a)) and showed the isotope pattern of $\mathrm{H}$-labeled peptide and D-labeled peptide (Figure 4(b)) which demonstrated the changes in different labeling. The statistical results showed that peak area was 4.42-fold in $\mathrm{D} / \mathrm{H}$ ratio and peak height was 4.22-fold; the statistical data was calculated and shown in Table 1.

3.4. Differentially Expressed Proteins of NRK-52E by Treatment with $\mathrm{Fe}_{3} \mathrm{O}_{4}$ NPs. In this study, we used $\mathrm{Fe}_{3} \mathrm{O}_{4}$ NPs to treat NRK-52E and used bioinformatics software to generate proteins identification and proteins quantitation
TABLE 1: The MS intensities of peptide GVDNTFADELVELSTALEHQEYITFLEDLK labeled $\mathrm{H}(\mathrm{m} / z$ 1165.92) and labeled $\mathrm{D}(\mathrm{m} / z$ $1168.60)$ in peak area and peak height.

\begin{tabular}{lcccc}
\hline$m / z$ & Peak area & Peak height & Ratio of area & Ratio of height \\
\hline 1165.92 & 4084412 & 1240520 & 4.42 & 4.22 \\
1168.60 & 18036323 & 5230797 & & \\
\hline
\end{tabular}

with a protein list (the protein list is shown in the electronic supplementary information available online in Supplementary Materials at http://dx.doi.org/10.1155/2014/754721). In the protein list, we observed that when $\mathrm{Fe}_{3} \mathrm{O}_{4} \mathrm{NPs}$ were treated, ras-related proteins were expressed including ras-related protein Rab-7L1 (RAB7L_RAT, 3.2-folds), ras-related protein Rab-1A (RAB1A_RAT, 2.3-folds), rasrelated protein Rab-2A (RAB2A_RAT, 1.6-folds), ras-related C3 botulinum toxin substrate 1 (RAC1_RAT, 1.2-folds), ras-related protein Rap-1A (RAP1A_RAT), and ras-related protein Rab-7a (RAB7A_RAT). Accor-ding to previous studies, ras-related proteins were associated with cancer cell metastasis [24, 25], and ras-related C3 botulinum toxin substrate 1 was associated with differential roles such as cell proliferation which could be inhibited by miR-101 [26] and signal transduction to upregulate in esophageal squamous cell carcinoma and esophageal adenocarcinoma [27].

We also identified related proteins in cell death and apoptosis, such as apoptotic protease-activating factor 1 (APAF_RAT, 780.9-folds), programmed cell death protein 10 (PDC10_RAT, 233.2-folds), galectin-1 (LEG1_RAT, 1.75folds), and programmed cell death 6-interacting protein 


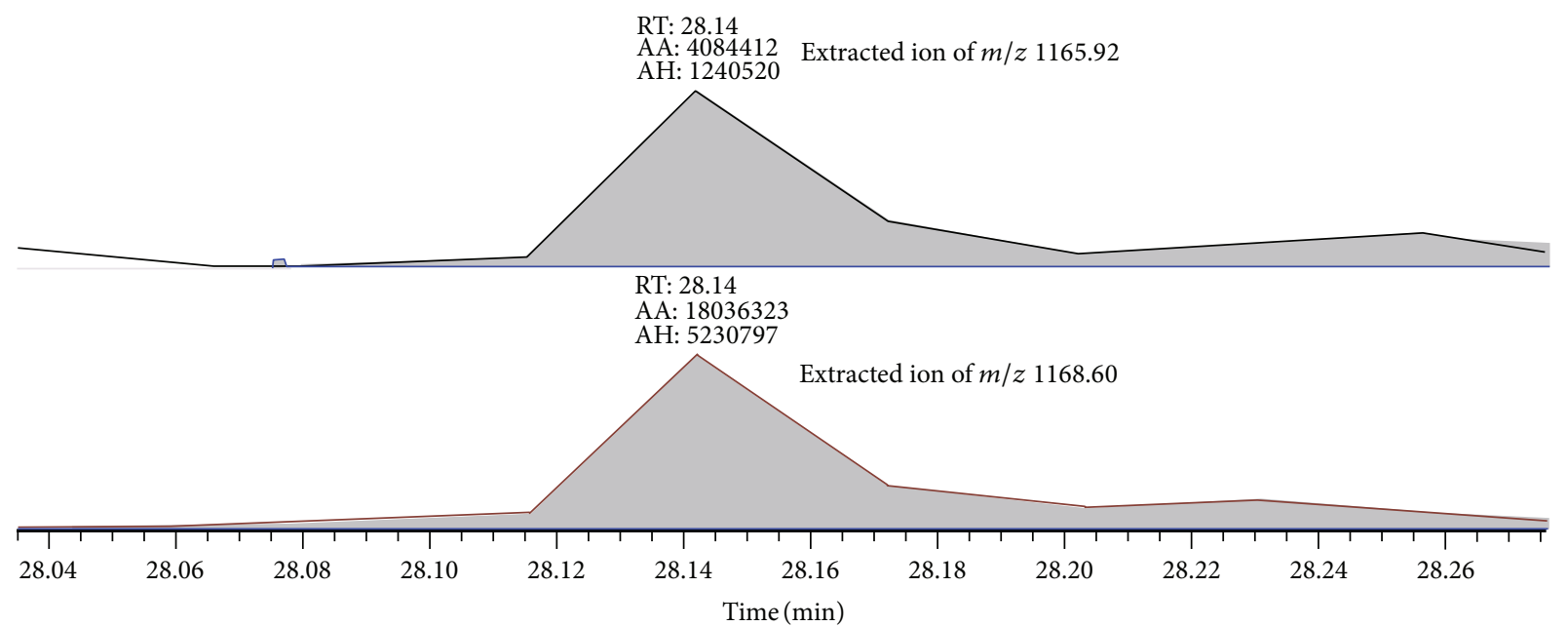

(a)

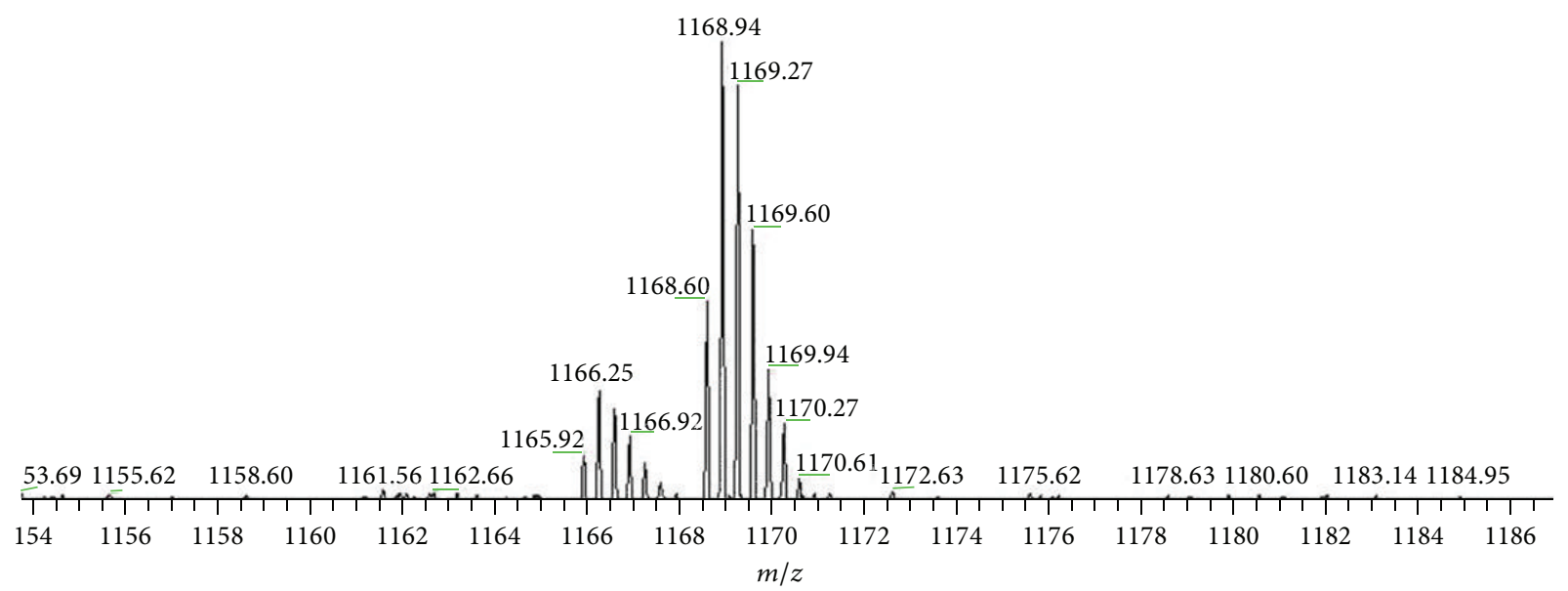

(b)

Figure 4: (a) Extracted ions of $\mathrm{m} / z 1165.92$ (H-labeled) and $\mathrm{m} / z 1165.92$ (D-labeled) showing signals of peak area (AA) and peak height (AH). (b) MS spectrum of GVDNTFADELVELSTALEHQEYITFLEDLK which are labeled formaldehyde- $\mathrm{H}_{2}$ and formaldehyde- $\mathrm{D}_{2}$. These two labeled peptides are shown in a coeluted isotopic pattern.

(PDC6I_RAT). Apoptotic protease-activating factor 1 activated procaspase-9 and modulated cellular apoptosis [28]. However, programmed cell death protein 10 promotes cell proliferation and protects malignant $\mathrm{T}$ cells from apoptosis [29]. The galectin family played different roles in cell apoptosis such as galectin-7 enhancing apoptosis, but galectin-1 has the opposite effect [30]. In accordance with previous studies and the proteins quantitative list, we considered that the treatment of $\mathrm{Fe}_{3} \mathrm{O}_{4}$ NPs caused an antagonistic effect. $\mathrm{Fe}_{3} \mathrm{O}_{4}$ NPs induced expression of ras-related proteins and induced programmed cell death protein 10 , galectin 1 to promote cell metastasis, proliferation, and progression. However, the apoptotic protease-activating factor 1 promoted cell to go to apoptosis.

A variety of glutathione-related proteins with high expression were identified, such as glutathione reductase (Fragment), glutathione S-transferase Mu 1, glutathione Stransferase $\mathrm{Mu} 2$, glutathione $\mathrm{S}$-transferase $\mathrm{P}$, and glutathione S-transferase alpha-3. We thought that $\mathrm{Fe}_{3} \mathrm{O}_{4}$ NPs induced reactive oxygen species (ROS) to cause overexpression of glutathione-related proteins. After one day of $\mathrm{Fe}_{3} \mathrm{O}_{4} \mathrm{NPs}$ treatment, a strong magnet was utilized to recover the residual NPs, but there were no NPs to be recycled. We considered that the NPs had transferred into ferric ions $\left(\mathrm{Fe}^{3+}\right)$ and ferrous ions $\left(\mathrm{Fe}^{2+}\right)$ and that endogenous hydrogen peroxide $\left(\mathrm{H}_{2} \mathrm{O}_{2}\right)$ reacted with ferrous ions to compose hydroxide free radicals (Fenton reaction) [31, 32]. A variety of reports show that ROS effects are exhibited when NPs were treated $[7,14]$. However, ferrous ion $\left(\mathrm{Fe}^{2+}\right)$ is an initiator in the Fenton reaction, and ferrous ions will react with hydrogen peroxide to produce hydroxide free radicals.

3.5. Chaperone Proteins Overexpression and STRING Networks Establishment. We also characterized chaperone proteins such as heat shock proteins, serpin $\mathrm{H} 1$, protein disulfideisomerase, endoplasmin, and endoplasmic reticulum resident protein. 
TABLE 2: Statistic classification of related proteins in NRK-52E cell lines with $\mathrm{Fe}_{3} \mathrm{O}_{4}$ NPs treatment.

\begin{tabular}{|c|c|c|c|c|c|}
\hline $\begin{array}{l}\text { UNIPROT } \\
\text { accession }^{\text {a }}\end{array}$ & $\begin{array}{l}\text { UNIPROT } \\
\text { accession } \\
\text { number }^{\mathrm{a}}\end{array}$ & Protein identification & $\begin{array}{c}\text { Molecular } \\
\text { mass }(\mathrm{kDa})^{\mathrm{b}}\end{array}$ & $\begin{array}{l}\text { Number of } \\
\text { peptides }^{b}\end{array}$ & Ratio $^{\mathrm{c}}$ \\
\hline \multicolumn{6}{|c|}{ Cell death and apoptosis related proteins } \\
\hline APAF_RAT & Q9EPV5 & Apoptotic protease-activating factor 1 & 146.1 & 2 & 780.9 \\
\hline PDC10_RAT & Q6NX65 & Programmed cell death protein 10 & 25.0 & 2 & 233.2 \\
\hline LEG1_RAT & P11762 & Galectin-1 & 15.5 & 5 & 1.75 \\
\hline PDC6I_RAT & Q9QZA2 & Programmed cell death 6-interacting protein & 99.2 & n.d. & n.d. \\
\hline \multicolumn{6}{|c|}{ Ras-related proteins } \\
\hline RAB7L_RAT & Q63481 & Ras-related protein Rab-7L1 & 23.7 & 2 & 3.2 \\
\hline RAB1A_RAT & Q6NYB7 & Ras-related protein Rab-1A & 23.4 & 13 & 2.3 \\
\hline RAB2A_RAT & P05712 & Ras-related protein Rab-2A & 24.1 & 3 & 1.6 \\
\hline RAC1_RAT & Q6RUV5 & Ras-related C 3 botulinum toxin substrate 1 & 22.4 & 2 & 1.2 \\
\hline RAP1A_RAT & P62836 & Ras-related protein Rap-1A & 21.8 & n.d. & n.d. \\
\hline RAB7A_RAT & P09527 & Ras-related protein $\mathrm{Rab}-7 \mathrm{a}$ & 24.3 & n.d. & n.d. \\
\hline \multicolumn{6}{|c|}{ Glutathione related proteins } \\
\hline GSHR_RAT & P70619 & Glutathione reductase (Fragment) & 47.8 & 2 & 3.1 \\
\hline GSTM1_RAT & P04905 & Glutathione S-transferase Mu 1 & 26.7 & 2 & 2.8 \\
\hline GSTM2_RAT & P08010 & Glutathione S-transferase Mu 2 & 26.5 & 3 & 2.4 \\
\hline GSTP1_RAT & P04906 & Glutathione S-transferase P & 24.1 & 6 & 1.5 \\
\hline GSTA3_RAT & P04904 & Glutathione S-transferase alpha-3 & 25.9 & 4 & 1.2 \\
\hline \multicolumn{6}{|c|}{ Chaperone proteins } \\
\hline HSBP1_RAT & Q8K3X8 & Heat shock factor-binding protein 1 & 8.7 & 2 & 2.8 \\
\hline HS90B_RAT & P34058 & Heat shock protein HSP 90-beta & 86.0 & 32 & 2.7 \\
\hline SERPH_RAT & P29457 & Serpin H1 & 47.7 & 30 & 2.5 \\
\hline HS90A_RAT & P82995 & Heat shock protein HSP 90-alpha & 87.7 & 31 & 2.4 \\
\hline HSP74_RAT & O88600 & Heat shock $70 \mathrm{kDa}$ protein 4 & 97.0 & 2 & 2.2 \\
\hline HSP7C_RAT & P63018 & Heat shock cognate $71 \mathrm{kDa}$ protein & 72.8 & 40 & 1.9 \\
\hline PDIA4_RAT & P38659 & Protein disulfide-isomerase A4 & 75.1 & 9 & 1.8 \\
\hline CH60_RAT & P63039 & $60 \mathrm{kDa}$ heat shock protein, mitochondrial & 62.6 & 29 & 1.6 \\
\hline CH10_RAT & P26772 & $10 \mathrm{kDa}$ heat shock protein, mitochondrial & 11.2 & 3 & 1.6 \\
\hline GRP78_RAT & P06461 & $78 \mathrm{kDa}$ glucose-regulated protein & 74.4 & 19 & 1.6 \\
\hline ENPL_RAT & Q66HD0 & Endoplasmin & 95.4 & 17 & 1.6 \\
\hline PDIA1_RAT & P04785 & Protein disulfide-isomerase & 59.1 & 24 & 1.6 \\
\hline ERP29_RAT & P52555 & Endoplasmic reticulum resident protein 29 & 29.3 & 3 & 1.6 \\
\hline PDIA6_RAT & Q63081 & Protein disulfide-isomerase A6 & 49.6 & 4 & 1.5 \\
\hline PDIA3_RAT & P11598 & Protein disulfide-isomerase A3 & 58.6 & 17 & 1.3 \\
\hline
\end{tabular}

Eventually, we used the STRING (vision 9.1, http://string$\mathrm{db}$.org/) database to establish the interactions between chaperone proteins and related proteins to demonstrate the relationships between $\mathrm{Fe}_{3} \mathrm{O}_{4}$ NPs and the associated proteins
[20]. The relationships between chaperone proteins, rasrelated proteins, glutathione related proteins, and cell death and apoptosis related proteins are listed in Table 2 and illustrated by STRING in Figure 5. Heat shock proteins connected 


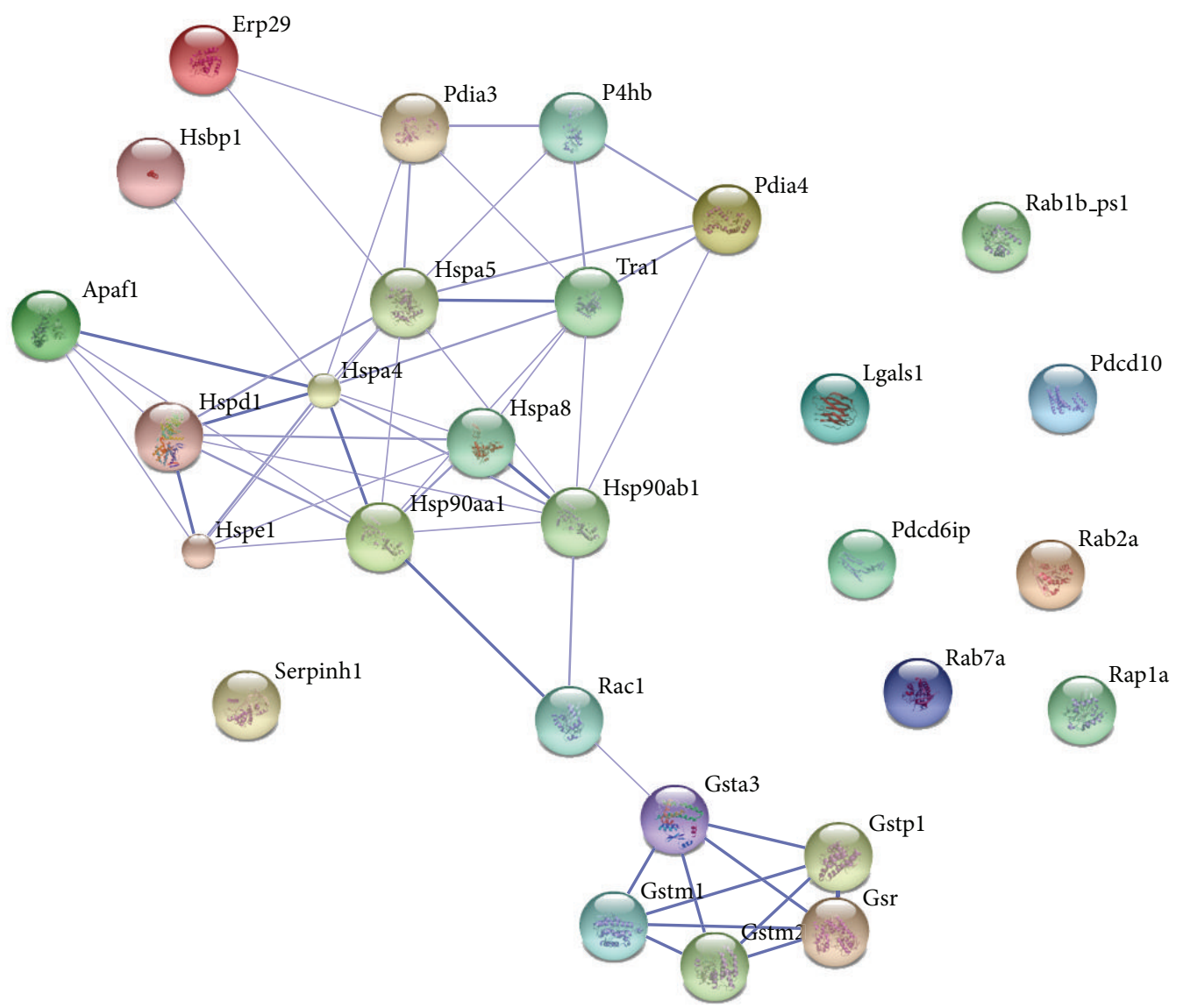

FIGURE 5: Schematic representation of the networks between cell death and apoptosis related proteins, ras-related proteins, glutathione related proteins, and chaperone proteins.

with each other and related ras-related C3 botulinum toxin substrate 1 and then combined to glutathione related proteins.

\section{Conclusion}

This is a pioneer experiment to show the cellular responses through $\mathrm{Fe}_{3} \mathrm{O}_{4}$ NPs treatment. We hypothesized an antagonistic effect in NRK-52E cell lines which is presented as cell death, apoptosis, and cancerization via programmed cell death protein and ras-related proteins; however there are protective mechanism proteins in NRK-52E such as chaperone proteins and glutathione related proteins. In future work, we shall generate or purchase $\mathrm{Fe}_{3} \mathrm{O}_{4}$ NPs in a smaller size to confirm the size effect of NPs, and we also need more evidence to prove the ROS effect induced via ferrous ions and to explain the tendency towards apoptosis or to avoid cell death.

\section{Conflict of Interests}

The all authors declare that they have no conflict of interests in this study.

\section{Acknowledgments}

This work was supported by a grant from the Kaohsiung Medical University Research Foundation (KMU-Q110023), with cooperation between the National Sun Yat-Sen University and Kaohsiung Medical University (NSYSUKMU 103P010) and the National Science Council (NSC 102-2113-M037-013-MY2), Taipei, Taiwan. The authors are thankful for the assistance of the Center for Resources, Research and Development of Kaohsiung Medical University.

\section{References}

[1] C. You, C. Han, X. Wang et al., "The progress of silver nanoparticles in the antibacterial mechanism, clinical application and cytotoxicity," Molecular Biology Reports, vol. 39, no. 9, pp. 91939201, 2012.

[2] A. Travan, C. Pelillo, I. Donati et al., "Non-cytotoxic silver nanoparticle-polysaccharide nanocomposites with antimicrobial activity," Biomacromolecules, vol. 10, no. 6, pp. 1429-1435, 2009.

[3] T. V. Mathew and S. Kuriakose, "Photochemical and antimicrobial properties of silver nanoparticle- encapsulated chitosan 
functionalized with photoactive groups," Materials Science and Engineering C, vol. 33, no. 7, pp. 4409-4415, 2013.

[4] W. Ding and L. Guo, "Immobilized transferrin $\mathrm{Fe}_{3} \mathrm{O}_{4} @ \mathrm{SiO}_{2}$ nanoparticle with high doxorubicin loading for dual-targeted tumor drug delivery," International Journal of Nanomedicine, vol. 8, no. 1, pp. 4631-4639, 2013.

[5] H. Zhang, K. E. Burnum, M. L. Luna et al., "Quantitative proteomics analysis of adsorbed plasma proteins classifies nanoparticles with different surface properties and size," Proteomics, vol. 11, no. 23, pp. 4569-4577, 2011.

[6] D. Simberg, J. Park, P. P. Karmali et al., "Differential proteomics analysis of the surface heterogeneity of dextran iron oxide nanoparticles and the implications for their in vivo clearance," Biomaterials, vol. 30, no. 23-24, pp. 3926-3933, 2009.

[7] M. Faria, J. M. Navas, A. M. Soares, and C. Barata, "Oxidative stress effects of titanium dioxide nanoparticle aggregates in zebrafish embryos," Science of the Total Environment, vol. 470471, pp. 379-389, 2014.

[8] B. Trouiller, R. Reliene, A. Westbrook, P. Solaimani, and R. H. Schiestl, "Titanium dioxide nanoparticles induce DNA damage and genetic instability in vivo in mice," Cancer Research, vol. 69, no. 22, pp. 8784-8789, 2009.

[9] P. Das, M. A. Xenopoulos, and C. D. Metcalfe, "Toxicity of silver and titanium dioxide nanoparticle suspensions to the aquatic invertebrate, Daphnia magna," Bulletin of Environmental Contamination and Toxicology, vol. 91, no. 1, pp. 76-82, 2013.

[10] T. Verano-Braga, R. Miethling-Graff, K. Wojdyla et al., Insights into the Cellular Response Triggered by Silver Nanoparticles Using Quantitative Proteomics, ACS Nano, 2014.

[11] F. Mirzajani, H. Askari, S. Hamzelou et al., "Proteomics study of silver nanoparticles toxicity on Bacillus thuringiensis," Ecotoxicology and Environmental Safety, vol. 100, pp. 122-130, 2014.

[12] X. Yang, C. Jiang, H. Hsu-Kim et al., "Silver nanoparticle behavior, uptake, and toxicity in Caenorhabditis elegans: effects of natural organic matter," Environmental Science \& Technology, vol. 48, no. 6, pp. 3486-3495, 2014.

[13] P. V. AshaRani, G. L. K. Mun, M. P. Hande, and S. Valiyaveettil, "Cytotoxicity and genotoxicity of silver nanoparticles in human cells," ACS Nano, vol. 3, no. 2, pp. 279-290, 2009.

[14] R. P. Singh and P. Ramarao, "Cellular uptake, intracellular trafficking and cytotoxicity of silver nanoparticles," Toxicology Letters, vol. 213, no. 2, pp. 249-259, 2012.

[15] W. Kim, J. Kim, J. D. Park, H. Y. Ryu, and I. J. Yu, "Histological study of gender differences in accumulation of silver nanoparticles in kidneys of Fischer 344 rats," Journal of Toxicology and Environmental Health A, vol. 72, no. 21-22, pp. 1279-1284, 2009.

[16] C.-J. Kuo, S.-S. Liang, E. Hsi, S.-H. Chiou, and S.-D. Lin, "Quantitative proteomics analysis of varicose veins: Identification of a set of differentially expressed proteins related to ATP generation and utilization," Kaohsiung Journal of Medical Sciences, vol. 29, no. 11, pp. 594-605, 2013.

[17] M. F. Ellias, S. H. Z. Ariffin, S. A. Karsani, M. A. Rahman, S. Senafi, and R. M. A. Wahab, "Proteomic analysis of saliva identifies potential biomarkers for orthodontic tooth movement," The Scientific World Journal, vol. 2012, Article ID 647240, 6 pages, 2012.

[18] S. B. Ficarro, Y. Zhang, M. J. Carrasco-Alfonso et al., "Online nanoflow multidimensional fractionation for high efficiency phosphopeptide analysis," Molecular \& Cellular Proteomics, vol. 10, no. 11, Article ID O111.011064, 2011.
[19] J. Hsu, S. Huang, N. Chow, and S. Chen, "Stable-isotope dimethyl labeling for quantitative proteomics," Analytical Chemistry, vol. 75, no. 24, pp. 6843-6852, 2003.

[20] A. Franceschini, D. Szklarczyk, S. Frankild et al., "STRING v9.1: protein-protein interaction networks, with increased coverage and integration," Nucleic Acids Research, vol. 41, no. 1, pp. D808D815, 2013.

[21] W.-Y. Chen and Y.-C. Chen, "Functional $\mathrm{Fe}_{3} \mathrm{O}_{4} @ \mathrm{ZnO}$ magnetic nanoparticle-assisted enrichment and enzymatic digestion of phosphoproteins from saliva," Analytical and Bioanalytical Chemistry, vol. 398, no. 5, pp. 2049-2057, 2010.

[22] H. Lin, W. Chen, and Y. Chen, "Iron oxide/tantalum oxide coreshell magnetic nanoparticle-based microwave-assisted extraction for phosphopeptide enrichment from complex samples for MALDI MS analysis," Analytical and Bioanalytical Chemistry, vol. 394, no. 8, pp. 2129-2136, 2009.

[23] K. Woo, J. Hong, S. Choi et al., "Easy synthesis and magnetic properties of iron oxide nanoparticles," Chemistry of Materials, vol. 16, no. 14, pp. 2814-2818, 2004.

[24] Y. X. Yin, F. Shen, H. Pei et al., "Increased expression of Rab25 in breast cancer correlates with lymphatic metastasis," Tumor Biology, vol. 33, no. 5, pp. 1581-1587, 2012.

[25] H. C. Adams III, R. Chen, Z. Liu, and I. P. Whitehead, "Regulation of breast cancer cell motility by T-cell lymphoma invasion and metastasis-inducing protein," Breast Cancer Research, vol. 12, no. 5, article R69, 2010.

[26] X. Lin, H. Guan, H. Li et al., "miR-101 inhibits cell proliferation by targeting Racl in papillary thyroid carcinoma," Bioscience Reports, vol. 2, no. 1, pp. 122-126, 2014.

[27] M. Bashir, D. Kirmani, H. F. Bhat et al., "P66shc and its downstream Eps8 and Racl proteins are upregulated in esophageal cancers," Cell Communication and Signaling, vol. 8, article 13, 2010.

[28] L. Mondragón, M. Orzáez, G. Sanclimens et al., "Modulation of cellular apoptosis with apoptotic protease-activating factor 1 (Apaf-1) inhibitors," Journal of Medicinal Chemistry, vol. 51, no. 3, pp. 521-529, 2008.

[29] B. Lauenborg, K. Kopp, T. Krejsgaard et al., "Programmed cell death-10 enhances proliferation and protects malignant $\mathrm{T}$ cells from apoptosis," APMIS, vol. 118, no. 10, pp. 719-728, 2010.

[30] B. Barkan, A. D. Cox, and Y. Kloog, "Ras inhibition boosts galectin-7 at the expense of galectin-1 to sensitize cells to apoptosis," Oncotarget, vol. 4, no. 2, pp. 256-268, 2013.

[31] E. W. Iyamu, H. Perdew, and G. M. Woods, "Cysteine-iron promotes arginase activity by driving the Fenton reaction," Biochemical and Biophysical Research Communications, vol. 376, no. 1, pp. 116-120, 2008.

[32] S. Toyokuni, "Iron and carcinogenesis: from Fenton reaction to target genes," Redox Report, vol. 7, no. 4, pp. 189-197, 2002. 

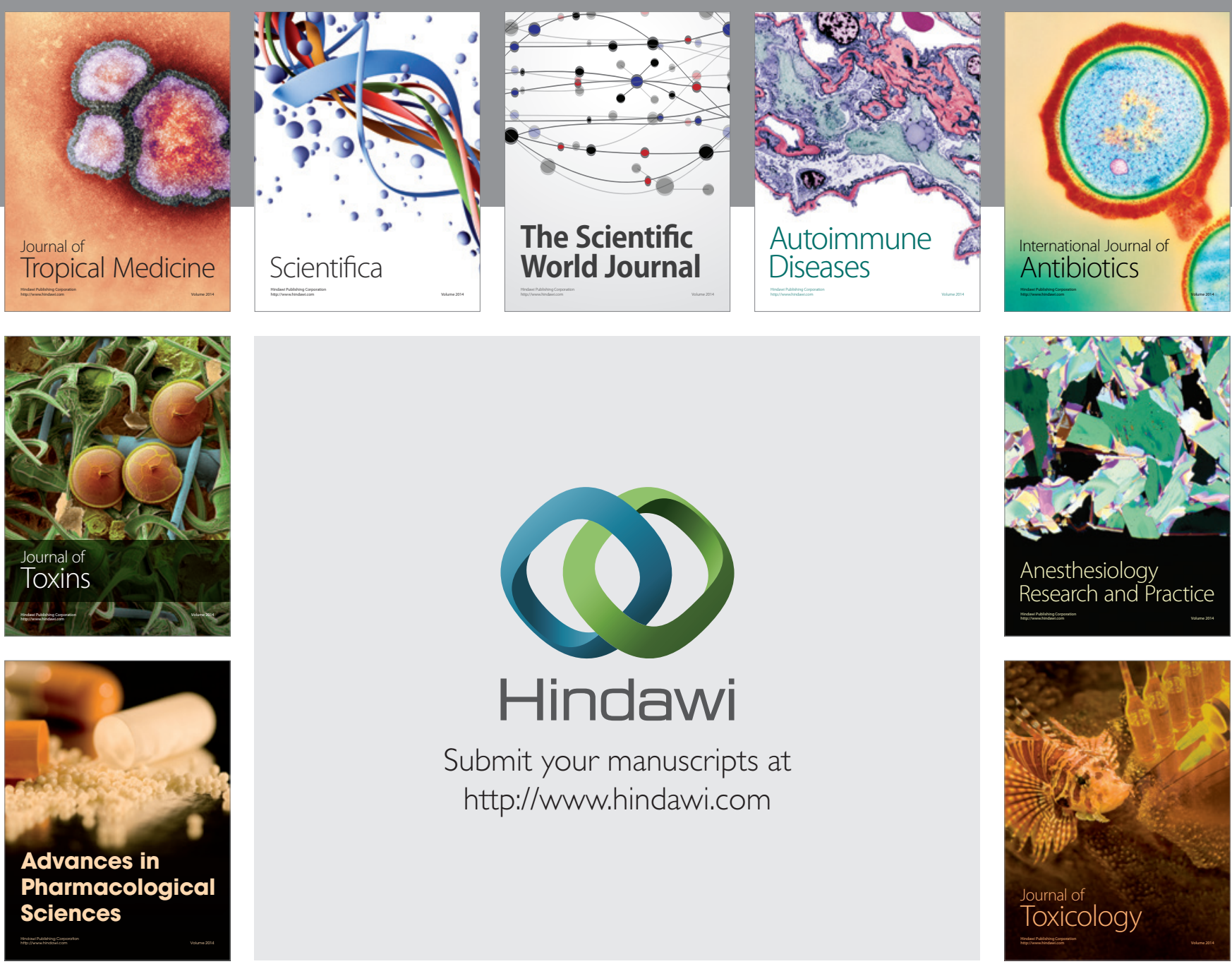

\section{Hindawi}

Submit your manuscripts at

http://www.hindawi.com
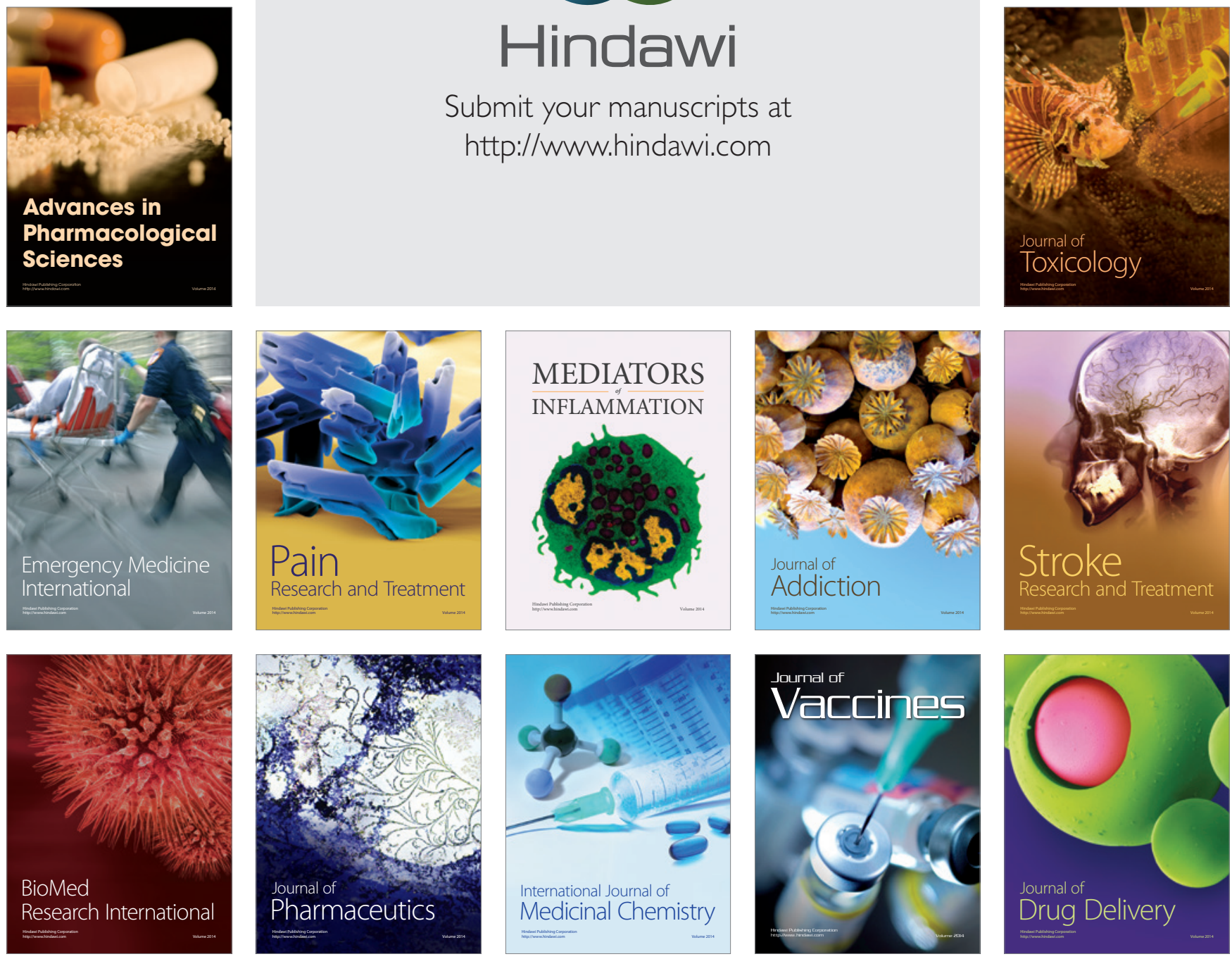